\title{
Interleukin 3 as an Erythropoietic Marker in Human Immunodeficiency Virus and Hepatitis B Positive Patients in South East Nigeria
}

\author{
Chinenye E. Okenwa ${ }^{1^{*}}$, ljeoma C. Uzoma ${ }^{1,2}$, Anulika O. Onyemelukwe ${ }^{1}$, \\ Ogechukwu C. Dozie-Nwakile ${ }^{1}$, Hilary Emuebie ${ }^{1}$, Victor C. Edeh ${ }^{1}$ \\ and S. A. Ufelle ${ }^{1}$ \\ ${ }^{1}$ Department of Medical Laboratory Science, Faculty of Health Sciences and Technology, \\ College of Medicine, University of Nigeria, Nsukka, Enugu Campus, Nigeria. \\ ${ }^{2}$ Department of Cell Biology and Genetics, Faculty of Science, University of Lagos, Akoka, Nigeria.
}

This work was carried out in collaboration among all authors. Author CEO designed the study, wrote the protocol and wrote the first draft of the manuscript. Author ICU performed the statistical analysis.

Author AOO and OCDN managed the analyses of the study. Authors HE and VCE managed the literature searches. Author SAU provided critical review of the article. All authors read and approved the final manuscript.

\section{Article Information}

DOI: $10.9734 / A R R B / 2020 / v 35 i 630231$ Editor(s):

(1) Ibrahim Farah, Jackson State University, USA. Reviewers:

(1) Urbano Solis Cartas, Universidad Nacional de Chimborazo, Ecuador.

(2) Ricardo Figueroa Damián, National Institute of Perinatology, Mexico. Complete Peer review History: http://www.sdiarticle4.com/review-history/58455

Original Research Article

Received 18 April 2020

Accepted 24 June 2020

Published 27 June 2020

\section{ABSTRACT}

Aim: To evaluate the interleukin 3 levels in some Hepatitis B virus and Human immunodeficiency virus (HIV) positive subjects.

Study Design: Cross sectional study.

Place and Duration of Study: Haematology Department, University of Nigeria Teaching Hospital Enugu, Nigeria, between June and September, 2019.

Methodology: A total of 86 subjects were recruited for this study; 40 were positive for the human immunodeficiency virus, 30 were Hepatitis B positive and 16 healthy subjects that served as controls. The controls had tested negative to Hepatitis B Virus, Human immunodeficiency Virus and hepatitis $C$ virus infections. Whole blood samples were collected from the Human immunodeficiency 
Virus positive and control samples. Haemoglobin concentration was analysed using the Orphěe Mythic 22 automated analyzer. Serum samples collected from all 86 subjects were used to assay Interleukin 3 using the Enzyme Linked Immunosorbent assay based Finetest human interleukin 3 kit.

Results: A highly significant decrease in interleukin 3 levels was observed in Hepatitis B Virus and Human immunodeficiency virus positive subjects when compared with the apparently healthy control subjects, $(P=0.000<0.05)$. Average hemoglobin levels were also lower in the Human immunodeficiency virus subjects compared with the controls.

Conclusion: A reduction of the interleukin 3 may be part of the synergistic factors responsible for the anaemia usually seen in the viral infections.

Keywords: Interleukin 3; haemoglobin; hepatitis B; human immunodeficiency virus; erythropoiesis; cytokines; growth factors.

\section{INTRODUCTION}

Acquired Immune Deficiency (AIDS) is a failure of the immune system. It occurs secondary to infection by the Human Immunodeficiency Virus (HIV). The HIV infection and its associated disease state AIDS remain a major public health problem. This is especially true for resource poor economies [1]. It results to severe damage to the immune responses of the affected individual. It also impairs haematological functions [2,3] Anaemia, thrombocytopenia and leucopenia are usually observed $[3,4]$. Cluster of differentiation CD4+ $T$ cells depletion is also a characteristic haematological dysfunction associated with HIV infection [5]. These haematological malfunctions serve as indicators of disease severity and prognosis. Cytopenia is generally a major diagnostic indication of disease [6].

Hepatitis B virus (HBV) infection is also a viral infection which results in a complex disease of the liver. It can be acute or chronic [7]. Due to the similarity of mechanism of spread of the two infections, it is not uncommon to find co-infection with HIV and the chronic disease form of Hepatitis $B$ [8]. It has been estimated that more than 380 million people worldwide have HBV worldwide [9].

The two diseases presently have no cure but can be effectively managed $(10,11)$. One important way of assessing management success is by monitoring the haematological and immunological parameters of the patients undergoing therapy $[10,12-14]$.

Interleukines are a complex group of proteins that function in the body. They mediate immune reactions. They also function as growth factors in haemopoiesis [15]. They have been generally incorporated in the management of haematological disorders [16]. In humans, more than 50 interleukins and related proteins have been identified. A key haemotopoietic interleukin is the interleukin 3 (IL3). It is produced in mast cells and activated T cells. It appears to serve as an bridge to immune responses affecting haemopoiesis [17]. This is by controlling response to infections by increasing immunity effector cells populations [18].

Interleukin-3 (IL-3) is a 28-kiloDalton glycoprotein. It was first identified in mice. Its major function is regulation of haemotocyte production [19]. It was found to induce the expression of 20-a-hydroxysteroid dehydrogenase (a marker of mature $T$ cells) in cultures of athymic mouse spleen cells [20]. This cytokine is expressed on activated T cells, mast cells and natural killer cells. The IL3 gene is expressed on the right lobe of the liver, the testis and in blood.

Activated $\mathrm{T}$ helper cells(Th) are a major source of IL 3 [17]. Th2 cells, also called CD4 cells are the major target of the HIV virus. Interleukin 3 can therefore be used to assess HIV prognosis. It also useful in cancer management, as it has been found to promote replenishment of white blood cells and platelets. It also improves the immune response [21]. This improves chemotherapy outcomes. Further work is also ongoing to explore greater use of interleukin 3 as a therapeutic factor in haematologic disorders [21]. Recombinant cytokines have been investigated in improvement of management of these two viral infections [22-26].

Recombinant IL3 has been found to be effective in increasing some haematological parameters in HIV infection [27]. These include total white cell 
counts, neutrophil counts and eosinophil counts. Recombinant IL3 has few side effects and stimulates haematologic response in normal bone marrow [28]. It has been used to increase eosinophil count as a way to treat parasitic infections [29]. It improves total neutrophil counts in aplastic bone marrow patients [30]. Haematological parameters are also restored to normal levels faster when IL3 is used in combination with other growth factors [31]. IL 3 has been found to stimulate haemopoietic stem cell expansion which in turn leads to improvement in the haematological profile.

Cytokine levels have been found to vary in some inflammatory and immunologic diseases [32-34] Cytokines like IL6 and tissue necrotic factors have been utilized as markers to determine pregnancy outcome in other viral hepatitis infections [35]. IL 17 which is also produced by $\mathrm{T}$ helper cells is found to increase in cases of chronic HBV infection [36]. It has been found that immune responses controlled by cytokines can determine disease prognosis [5,37]. Other interleukines e.g. IL 4 has been shown to inhibit viral replication of HBV [38]. Disease prognosis seemed favourable in a study assessing the effect of recombinant IL4 on chronic HBV infection [39]. IL 6 administration has also been found to reduce the cellular infection by HBV [40].

Improved haemopoiesis remains a need in patients undergoing anti-viral therapy. It has been observed that the immune damage caused by the HIV isn't only attributed or caused by the virus mediated killing [5]. Most of the anti-viral drugs have a depressive effect on haemopoiesis which could be a source of pancytopenia. Viral infections generally have myriad effects on haemopoiesis and the bone marrow [12].

There is a need for improvements in the management therapies of people already infected with HIV and HBV. It is therefore worthwhile to study some of the haemopoietic growth factors in these infections. In addition, a study of the cytokines may be beneficial to understanding better the interplay between these viral infections and the immune system.

Therefore, the aim of the study is assess IL3 levels in HIV and HBV positive Nigerian patients.

\section{MATERIALS AND METHODS}

\subsection{Study Population and Data Collection}

A total of Eighty-six (86) participants (males and females) were involved in this study. The inclusion criteria for this study includes; age between 19-64 years, no history of any significant medical conditions including high blood pressure, malignancies or known haematological disorders. Only participants willing and able to give informed consent were included. All were screened for HBV, HIV and $\mathrm{HCV}$. None were on any chemotherapeutic drugs or had signs of malnutrition. The first test group consisted of 40 participants positive for HIV only, and on antiretroviral therapy for a minimum of one year. The second group of 30 participants were positive for HBV only. The HIV and HBV positive groups all had no clinical manifestation of the disease and were asymptomatic (Stage I HIV). The control group consisted of apparently healthy 16 subjects who tested negative for HIV, $\mathrm{HBV}$ and HCV. Pregnant and breastfeeding women were excluded. Questionnaires were used to obtain demographic information about the participants.

\subsection{Study Area and Design}

The study was conducted in Enugu, the capital city of Enugu State Nigeria. The study lasted between June and September 2019. The study adopted a cross-sectional approach.

\subsection{Laboratory Analysis}

Three (3) $\mathrm{ml}$ of blood was collected from the ante-cubital vein of the subjects and transferred into Ethylene Diamine Tetra-acetic Acid (EDTA) containers with the anticoagulant at a concentration of $1.6 \mathrm{mg} / \mathrm{ml}$ of blood.

\subsubsection{Haemoglobin concentration}

Haemoglobin concentration was assayed using the Orphěe Mythic 22 automated analyzer.

\subsubsection{Interleukin 3 assay}

This was assayed via ELISA, using the Finetest human interleukin 3 ELISA kit. The tests were run according to the manufacturer's instructions. 


\subsection{Statistical Analysis}

The data obtained from this study was analyzed with SPSS version 20.0 (SPSS Inc., Chicago, IL, USA). Comparison of the plasma IL-3 between HIV-test and control subjects was done using the $t$ test. A $P$-value of less than (<) 0.05 was chosen as statistically significant.

\section{RESULTS AND DISCUSSION}

Data obtained from this study shows that there was a decrease in the mean values for IL3 in both HIV and HBV positive individuals when compared with the control group. This work assayed the IL- 3 levels in patients with either HIV or HBV and compared it with controls (Table 1). Furthermore, the total haemoglobin values of the HIV positive people were compared to their total IL3 values. This was to check for the correlation between IL3, a haemopoietic factor, and total haemoglobin values. The difference in IL3 values between the test and control groups was also highly statistically significant, with the $P$ value being $=.001($ Table 1$)$.

When the means of the IL3 levels HBV, HIV and controls were compared, it was evident that there was a marked difference between the test cohort and the control cohort (Fig. 1)

Prior studies investigating the effects of these two viral infections on cytokine levels and the immune response to them have been done [41]. Cytokines are markers of inflammation. HIV and HBV infection are both viral infections with inflammatory properties $[10,42,43]$. Cytokine levels have been found to vary depending on type and stage of disease, $[44,45]$ and have long been considered as therapeutic agents for the management of HIV and HBV infections [22,25,46-49]. IL- 2 in combination with IL- 16 could help in stimulating the immune response in HIV patients, increasing CD4+ cell populations [22].

Like earlier mentioned, depending on disease stage and severity, cytokines tend to have different disease responses. IL 35 has been found to decrease in chronic HBV infection [50], while the same IL 35 also has been found to increase in acute HBV patients [51]. This probably leads to an establishment of the infection. IL 35 is an anti-inflammatory cytokine, it suppresses inflammatory response. Other studies investigating the role of $\mathrm{IL} 35$ as a

Table 1. Demographic characteristics, Haemoglobin in HIV and interlekin 3 level in HIV and HBV positive cases and controls

\begin{tabular}{lllll}
\hline Parameters & Control $(\mathbf{n}=\mathbf{1 6})$ & HIV $(\mathbf{n}=\mathbf{4 0})$ & HBV $(\mathbf{n}=\mathbf{3 0})$ & \\
\hline $\mathrm{M}$ & 15 & 13 & - & \\
$\mathrm{F}$ & 1 & 27 & - & \\
Age (years0 & $18-65$ & $18-65$ & $18-65$ & \\
\hline & $($ Mean \pm SD) & & & $P$ value \\
\hline Haemoglobin $(\mathrm{g} / \mathrm{dl})$ & $14.6 \pm 1.0$ & $11.3 \pm 1.5$ & - & \\
Interleukin 3 $(\mathrm{pg} / \mathrm{ml})$ & $687.8 \pm 191.4$ & $557.3 \pm 127.5$ & $608.6 \pm 143$ & $=.001$ \\
\hline
\end{tabular}

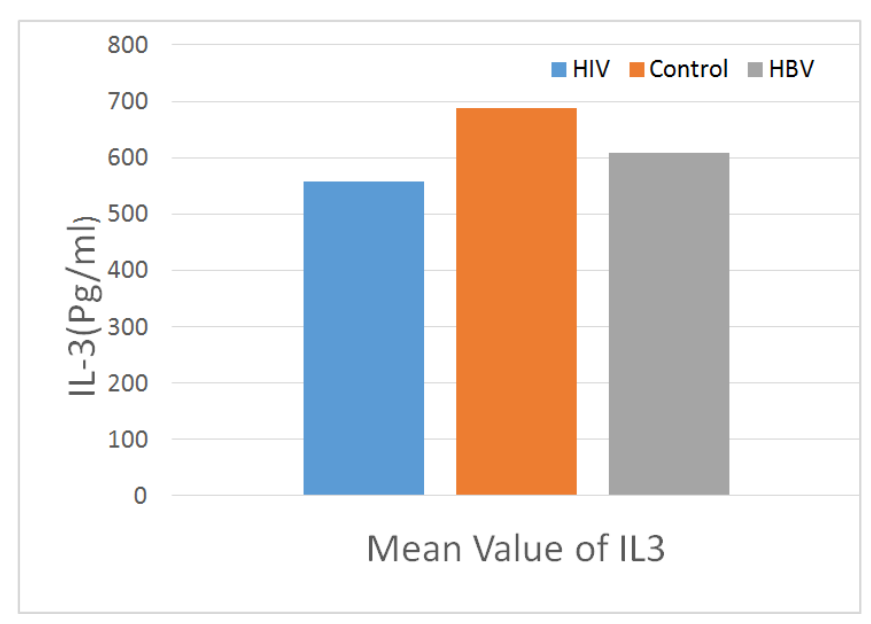

Fig. 1. Comparing IL3 means of HIV, HBV and controls 
therapeutic agent in chronic HBV are ongoing [52]. Though, due to time constraints, the present study was not able to separate the subjects into chronic and acute infections. Acute and chronic infections have different cytokine patterns. However, cytokine depression has been found to enhance infective capacity of HBV [53].

Pro - inflammatory cytokines levels are usually elevated in hepatitis. IL-6, a pro inflammatory cytokine has been found to increase in HBV infection. This is to be expected as HBV has inflammatory effects on the liver.

Simple assays similar to that in this study have also been done just to assess levels of different cytokines in these diseases. IL- 1 was found to be increased while IL- 2 was found to be decreased compared to controls in patients with chronic HBV [54]. Other studies showed that IL-6 and IL-10 levels were higher in ART naïve HIV subjects when compared to ART experienced subjects [10]. This is to be expected because both IL6 and IL10 are both inflammatory markers.

Antiretroviral therapy tends to suppress cytokines. Though inflammatory cytokines appear to rise in untreated HIV, treatment tends to reduce the levels [55]. One limitation of this study was the inability to get naïve HIV subjects.

Of interest is the fact that recombinant inlerleukin 3 has already been studied as a therapeutic agent to treat cytopenia. Red blood cell indices and haematocrit values were generally unchanged. Though some patients showed improvements in hemoglobin values with IL 3 injection.

Anaemia is a common finding in HIV infection, with rates of its occurrence increasing with disease progression [56]. The aetiology of this anaemia is heterogenous [57]. It ranges from suppression of erythropoiesis by lymphoma cells, bacterial co-infections e.g. tuberculosis, nutritional deficiencies, anti-viral therapy etc. $[13,58,59]$. Results from this study also seem to inform that interleukin 3 which is a haemopoietic growth factor seems to be depressed in these 2 viral infections. Its decrease is also directly proportional to haemoglobin concentration. This is complementary to earlier studies in HIV patients on erythropoietin levels, another haemopoietic growth factor [56]. Levels appeared to be lower than expected in response to anaemia in HIV patients. The erythropoietic response was also depressed. This could be due to the effects of antiviral drugs.

Further work is still necessary. This may be helpful to determine if all the decreases vary with acute or chronic infections. Other haemopoietic growth factors for instance erythropoietin, granulocyte- macrophage colony stimulating factor (GM-CSF), interleukin 11, granulocyte colony stimulating factor (G CSF) can also be assayed as a profile to fully understand the effects of these viral infections on haemopoiesis. Already, recombinant erythropoietin is standardly used in treatment of anaemia [24]. Interleukin 3 has potential as a therapeutic agent for use in improving haemoglobin concentration in HIV and HBV patients with cytopenia. As IL 3 has been studied for use in treating bone marrow failure [28], and in management of cancers in combination with other agents [60], it could also be incorporated into the HIV treatment cocktail.

\section{CONCLUSION}

In conclusion, IL3 levels are decreased in people with HIV and HBV infections compared with controls. Supplementation with external sources of this cytokine could help in improving disease management outcomes.

\section{CONSENT AND ETHICAL APPROVAL}

This study was conducted after obtaining ethical clearance from Health Research and Ethics committee of the University of Nigeria Teaching Hospital, Ituku/Ozalla, Enugu, with approval number NHREC/05/01/2008B-FWA000024581RB00002323. Prior to recruitment, details of the procedures involved in the study were explained to the participants, those who gave their consent by signing the informed consent form were recruited for the study. Anonymity and confidentiality of participants' data were maintained throughout the study. Participants were also informed of their right to withdraw from the study at any time. The study was designed with minimal attendant risk to participants.

\section{COMPETING INTERESTS}

Authors have declared that no competing interests exist.

\section{REFERENCES}

1. Ford N, Vitoria M, Penazzato M, Doherty M, Shubber Z, Meintjes G, et al. Causes of hospital admission among people living 
with HIV worldwide: A systematic review and meta-analysis. Lancet HIV; 2015.

2. Parinitha S, Kulkarni M. Haematological changes in HIV infection with correlation to CD4 cell count. Australas Med J. 2012; 5(3):157.

3. Katemba C, Muzoora C, Muwanguzi E, Mwambi B, Atuhairwe C, Taremwa IM. Hematological abnormalities in HIVantiretroviral therapy naïve clients as seen at an immune suppression syndrome clinic at Mbarara regional referral hospital, southwestern Uganda. J Blood Med. 2018;9:105-10.

4. Vishnu P, Aboulafia DM. Haematological manifestations of human immune deficiency virus infection. $\mathrm{Br} \mathrm{J}$ Haematol; 2015.

5. Tincati C, Monforte A, Marchetti G. Immunological Mechanisms of Interleukin2 (IL-2) Treatment in HIVIAIDS Disease. Curr Mol Pharmacol [Internet]. 2010;2 (1):40-5.

[Cited 2020 Mar 9]

Available:http://www.ncbi.nlm.nih.gov/pub $\mathrm{med} / 20021444$

6. Singh A, Hungund B, Kumar L, Pattanshetti M. Clinico-haematological profile of patients with bicytopenia. Pathology; 2018.

7. Trépo C, Chan HLY, Lok A. Hepatitis B virus infection. Vol. 384, The Lancet. Lancet Publishing Group. 2014;2053-63.

8. Burnett RJ, Francois G, Kew MC, LerouxRoels G, Meheus A, Hoosen AA, et al. Hepatitis B virus and human immunodeficiency virus co-infection in subSaharan Africa: A call for further investigation. Liver International; 2005.

9. Chisari FV. Ferrari C. Hepatitis B Virus Immunopathogenesis. Annu Rev Immunol; 1995.

10. Akase IE, Musa BOP, Obiako RO, Ahmad Elfulatiy A, Mohammed AA. Immune Dysfunction in HIV: A Possible Role for Pro- and Anti-Inflammatory Cytokines in HIV Staging. J Immunol Res; 2017.

11. Sulkowski MS. Viral hepatitis and HIV coinfection. Journal of Hepatology; 2008.

12. Pascutti MF, Erkelens MN, Nolte MA. Impact of viral infections on hematopoiesis: From beneficial to detrimental effects on bone marrow output. Frontiers in Immunology; 2016.

13. Moore RD. Human Immunodeficiency Virus Infection, Anemia and Survival. Clin Infect Dis; 1999.
14. Khorami SHH, Nejatollahi F, Davarpanah MA. Serum levels of interleukin-4, interleukin-10 and interferon- $y$ in patients with chronic hepatitis B infection. Hepat Mon. 2018;18(4).

15. Robb L. Cytokine receptors and hematopoietic differentiation. Oncogene 20072647 [Internet]. 2007;26(47):671523.

Available:http://www.nature.com/articles/12 10756

16. Filshie R. Cytokines in Haemopoietic Progenitor Mobilisation for Peripheral Blood Stem Cell Transplantation. Curr Pharm Des; 2005.

17. Ihle JN. Interleukin-3 and hematopoiesis. Chemical Immunology; 1992.

18. Lantz CS, Boeslger J, Song CH, Mach N, Kobayashi T, Mulligan RC, et al. Role for interleukin-3 in mast cell and basophil development and in immunity to parasites. Nature; 1998.

19. Metcalf D. Hematopoietic Cytokines. Blood [Internet]. 2008;111(2):485-91.

Available:http://www.ncbi.nlm.nih.gov/pub $\mathrm{med} / 18182579$

20. Ihle JN, Pepersack L, Rebar L. Regulation of $\mathrm{T}$ cell differentiation: in vitro induction of 20 alpha-hydroxysteroid dehydrogenase in splenic lymphocytes from athymic mice by a unique lymphokine. J Immunol [Internet]. 1981; 126(6).

Available:https://www.jimmunol.org/content /126/6/2184

21. McBride WH, Dougherty GD, Wallis AE, Economou JS, Chiang CS. Interleukin-3 in gene therapy of cancer. Folia Biol (Praha); 1994.

22. Hornfeld $\mathrm{H}$, Cruikshank W. Prospects for IL-16 in the Treatment of AIDS. Expert Opin Biol Ther [Internet]. 2001;1(3):42532.

Available:http://www.ncbi.nlm.nih.gov/pub med/11727516

23. Shao X, Ma J, Jia S, Yang L, Wang W, Jin Z. Interleukin-35 suppresses antiviral immune response in chronic hepatitis $B$ virus infection. Front Cell Infect Microbiol; 2017.

24. Ng T, Marx G, Littlewood T, Macdougall I. Recombinant erythropoietin in clinical practice. Postgraduate Medical Journal; 2003.

25. Martí-Carvajal AJ, Solà I, Peña-Martí GE, Comunián-Carrasco G. Treatment for anemia in people with AIDS. Cochrane Database Syst Rev; 2011. 
26. Guidotti LG, Guilhot,' And S, Chisarii FV. Interleukin-2 and alpha/beta interferon down-regulate hepatitis $B$ virus gene expression in vivo by tumor necrosis factor-dependent and-independent pathwayst [Internet]. Journal of Virology. 1994.

[Cited 2020 Mar 9]

Available:http://jvi.asm.org/Downloadedfro m1266GUIDOTrIETAL

27. Scadden DT, Levine JD, Bresnahan J, Gere J, Mcgrath J, Wang Z, et al. In Vivo Effects of Interleukin 3 in HIV Type 1Infected Patients with Cytopenia. AIDS Res Hum Retroviruses; 1995.

28. Falk S, Seipelt G, Ganser A, Ottmann O, Hoelzer D, Stutte $H$, et al. Bone Marrow Findings After Treatment With Recombinant Human interleukin-3. Am J Clin Pathol [Internet]. 1991;95(3):355-62.

Available:http://www.ncbi.nlm.nih.gov/pub med/1996545

29. Morris KR, Bean AGD, Bruce MP, Broadway MM, O'Neil TE, Andrew ME, et al. Administration of porcine interleukin-3 induces increased levels of blood eosinophils. J Interf Cytokine Res [Internet]. 2008;28(7):435-43.

[Cited 2020 Mar 9]

Available:http://www.ncbi.nlm.nih.gov/pub med/18597621

30. Ganser A, Lindemann A, Seipelt G, Ottmann O, Eder M, Falk S, et al. Effects of Recombinant Human interleukin-3 in Aplastic Anemia. Blood [Internet]. 1990; 76(7):1287-92.

Available:http://www.ncbi.nlm.nih.gov/pub $\mathrm{med} / 2207306$

31. Lemoli RM, Fogli M, Fortuna A, Amabile M, Zucchini P, Grande A, et al. Interleukin-11 (IL-11) acts as a synergistic factor for the proliferation of human myeloid leukaemic cells. Br J Haematol. 1995;91(2):319-26.

[Cited 2020 Mar 9]

Available:http://doi.wiley.com/10.1111/j.13 65-2141.1995.tb05296.x

32. Zhang J, Zhang Y, Wang Q, Li C, Deng H, $\mathrm{Si} \mathrm{C}$, et al. Interleukin-35 in immunerelated diseases: protection or destruction. Immunology. Blackwell Publishing Ltd. 2019;157:13-20.

33. Asadullah K, Sterry $\mathrm{W}$, Volk HD. Interleukin-10 therapy - Review of a new approach. Pharmacological Reviews; 2003.

34. Gauvreau GM, Ellis AK, Denburg JA. Haemopoietic processes in allergic disease: Eosinophil/basophil development. Clinical and Experimental Allergy; 2009.

35. Kumar A, Devi SG, Kar P, Agarwal S, Husain SA, Gupta RK, et al. Association of cytokines in hepatitis $E$ with pregnancy outcome. Cytokine. 2014;65(1):95104.

36. Du WJ, Zhen JH, Zeng ZQ, Zheng ZM, Xu $Y$, Qin LY, et al. Expression of Interleukin17 associated with disease progression and liver fibrosis with hepatitis B virus infection: IL-17 in HBV infection. Diagn Pathol; 2013;

37. Senn JJ, Klover PJ, Nowak IA, Mooney RA. Interleukin-6 induces cellular insulin resistance in hepatocytes. Diabetes; 2002.

38. Lin S-J, Shu PY, Chang C, Ng AK, Hu C. IL-4 Suppresses the Expression and the Replication of Hepatitis B Virus in the Hepatocellular Carcinoma Cell Line Hep3B. J Immunol. 2003;171(9):4708-16.

39. Kakumu S, Fuji A, Yoshioka K, Tahara H, Ohtani $\mathrm{Y}$, Hirofuji $\mathrm{H}$, et al. Pilot study of recombinant human interleukin 2 for chronic type B hepatitis. Hepatology [Internet]. 1988;8(3):487-92.

[Cited 2020 Mar 9]

Available:http://doi.wiley.com/10.1002/hep. 1840080309

40. Bouezzedine F, Fardel O, Gripon P. Interleukin 6 inhibits HBV entry through NTCP down regulation. Virology. 2015 Jul 1;481:34-42.

41. Watashi $\mathrm{K}$, Liang $\mathrm{G}$, Iwamoto $\mathrm{M}$, Marusawa $H$, Uchida $N$, Daito $T$, et al. Interleukin-1 and tumor necrosis factor- $\alpha$ trigger restriction of hepatitis $b$ virus infection via a cytidine deaminase activation-induced cytidine deaminase (AID). J Biol Chem. 2013;288(44):3171527.

42. Hösel M, Quasdorff $M$, Wiegmann $K$, Webb D, Zedler U, Broxtermann M, et al. Not interferon, but interleukin-6 controls early gene expression in hepatitis B virus infection. Hepatology [Internet]. 2009;50 (6):1773-82.

[Cited 2020 Mar 9]

Available:http://www.ncbi.nlm.nih.gov/pub med/19937696

43. Li X, Liu X, Tian L, Chen Y. Cytokinemediated immunopathogenesis of hepatitis $B$ virus infections. Clinical Reviews in Allergy and Immunology. Humana Press Inc. 2016;50:41-54.

44. Onishi RM, Gaffen SL. Interleukin-17 and its target genes: Mechanisms of 
interleukin-17 function in disease. Immunology; 2010.

45. Zhou Y, Zhang H, Li Y. IL-35 expression in peripheral blood CD4+ T cells from chronic hepatitis $B$ virus-infected patients directly correlates with virus load. Cytokine; 2015.

46. Takebe N, Paredes J, Pino M, Lownsbury W, Agosti J, Krown S. Phase I/II Trial of the type i soluble recombinant human interleukin-1 receptor in HIV-1-infected Patients. J Interferon Cytokine Res [Internet]. 1998;18(5): 321-6.

Available:http://www.ncbi.nlm.nih.gov/pub $\mathrm{med} / 9620359$

47. Frank AC, Zhang $X$, Katsounas $A$, Bharucha JP, Kottilil S, Imamichi $T$. Interleukin-27, an anti-HIV-1 cytokine, inhibits replication of hepatitis $\mathrm{C}$ virus. $\mathrm{J}$ Interf Cytokine Res; 2010.

48. Xiang XG, Xie $Q$. IL-35: A potential therapeutic target for controlling hepatitis $B$ virus infection. J Dig Dis; 2015.

49. Xia $Y$, Protzer U. Control of hepatitis B virus by cytokines. Viruses. MDPI AG. 2017;9.

50. Cheng ST, Yuan D, Liu Y, Huang Y, Chen $X, Y u H B$, et al. Interleukin-35 level is elevated in patients with chronic hepatitis $B$ virus infection. Int J Med Sci. 2018; 15(2):188-94.

51. Teng DK, Liu Y, Lv YF, Wang L, Zhang W, Wang JP, et al. Elevated interleukin-35 suppresses liver inflammation by regulation of $\mathrm{T}$ helper 17 cells in acute hepatitis B virus infection. Int Immunopharmacol; 2019.

52. Yang L, Jia S, Shao X, Liu S, Zhang Q, Song $\mathrm{J}$, et al. Interleukin-35 modulates the balance between viral specific $\mathrm{T}$ cells and $\mathrm{T}$ helper 17 cells in chronic hepatitis $\mathrm{B}$ virus infection. 2019;(218):1-10.
53. Shlomai A, Schwartz RE, Ramanan V, Bhatta A, De Jong YP, Bhatia SN, et al. Modeling host interactions with hepatitis $B$ virus using primary and induced pluripotent stem cell-derived hepatocellular systems. Proc Natl Acad Sci U S A; 2014.

54. Anastassakos C, Alexander GJM, Wolstencroft RA, Avery JA, Portmann BC, Panayi GS, et al. Interleukin-1 and interleukin-2 activity in chronic hepatitis B virus infection. Gastroenterology. 1988; 94(4):999-1005.

55. Freeman $\mathrm{ML}$, Shive $\mathrm{CL}$, Nguyen TP, Younes SA, Panigrahi S, Lederman MM. Cytokines and T-Cell Homeostasis in HIV Infection. J Infect Dis [Internet]. 2016; 214:S51-7.

[Cited 2020 Mar 9]

Available:https://www.ncbi.nlm.nih.gov/pm c/articles/PMC6373575/

56. Spivak JL, Barnes DC, Fuchs E, Quinn TC. Serum immunoreactive erythropoietin in HIV-infected patients. JAMA J Am Med Assoc; 1989.

57. O'Connell C, Levine AM. Managing anemia in HIV-positive women. Vol. 2, Women's Health. 2006;159-65.

58. Makubi A, Okuma J, Spiegelman D, Hawkins C, Darling AM, Jackson E, et al. Burden and determinants of severe anemia among HIV-infected adults: Results from a large urban HIV Program in Tanzania, East Africa. J Int Assoc Provid AIDS Care. 2015;14(2): 148-55.

59. Parinitha SS, Kulkarni MH. Haematological changes in HIV infection with correlation to CD4 cell count. Australas Med J; 2012.

60. Mangi $M$, Newland $A$. Interleukin-3 in hematology and oncology: Current State of knowledge and future directions. cytokines cell mol ther [Internet]. 1999;5 (2):87-95. Available:http://www.ncbi.nlm.nih.gov/pub $\mathrm{med} / 10515681$

(c) 2020 Okenwa et al.; This is an Open Access article distributed under the terms of the Creative Commons Attribution License (http://creativecommons.org/licenses/by/4.0), which permits unrestricted use, distribution, and reproduction in any medium, provided the original work is properly cited.

Peer-review history:

The peer review history for this paper can be accessed here: http://www.sdiarticle4.com/review-history/58455 